\title{
Maternal MTHFR A1298C polymorphism and risk of congenital heart disease in fetus
} Vandana Rai

Department of Biotechnovogy

V B S Purvanchal University

Jaunpur-222003,UP

Correspondence: raivandana@rediffmail.com

\begin{abstract}
:
Methylenetetrahydrofolate reductase (MTHFR) is an important enzyme involved in folate metabolism, DNA synthesis and methylation. A number of studies have examined the association of maternal MTHFR A1298C polymorphism with congenital heart disease (CHD) susceptibility; however, the conclusions were contradictory. To clarify the influence of maternal MTHFR A1298C polymorphism on CHD, a meta-analysis of seventeen casecontrol studies was carried out. Four electronic databases - Pubmed, Google Scholars, Elsevier and Springer Link were searched upto June, 2018 for suitable articles. The pooled odds ratios (ORs) with 95\% confidence intervals (95\% CIs) were used to evaluate the association. Meta-analysis was performed by Mix and MetaAnalyst programs.

The results of meta-analysis suggested that except co-dominant model, maternal A1298C polymorphism is risk for CHD in fetus using overall comparisons in four genetic models $(\mathrm{C}$ vs. $\mathrm{A}: \mathrm{OR}=1.19,95 \% \mathrm{CI}=1.00-1.41, \mathrm{p}=0.04$; $\mathrm{CC}+\mathrm{AC}$ vs. $\mathrm{AA}: \mathrm{OR}=1.19,95 \% \mathrm{CI}=0.97-1.4, \mathrm{p}=0.04$; $\mathrm{CC}$ vs. $\mathrm{AA}: \mathrm{OR}=1.46,95 \% \mathrm{CI}=1.00-2.13, \mathrm{p}=0.04$; $\mathrm{AC}$ vs. AA $\mathrm{OR}=1.13,95 \% \mathrm{CI}=0.93-1.36, \mathrm{p}=0.23$; $\mathrm{CC}$ vs. $\mathrm{AC}+\mathrm{AA}: \mathrm{OR}=1.34,95 \% \mathrm{CI}=1.1-1.6, \mathrm{p}=0.01$ ). Publication bias was absent using four genetic models. In conclusion, results of present meta-analysis showed significant association between maternal MTHFR A1298C polymorphism and CHD risk.
\end{abstract}

\section{Keywords:}

Congenital Heart Disease, CHD, MTHFR, A1298C, Polymorphism, Meta-analysis

\section{Introduction:}

Cardiac malformations rank among the most common congenital malformations. The incidence of congenital heart disease (CHD) is about 8 per 1000 live birth (Mitchell et al., 1971; Hofmann and Christianson, 1978; Winter et al.,2007) and are mainly due to incomplete development of the heart during pregnancy (Bozovic et al., 2011). Their origin is considered to be multifactorial, resulting from an interaction between genetic predisposition and environmental factors. Periconceptional folic acid, reduces the risk of CHD like -neural tube defects (NTD) (Czeizel and Dudas, 1992). Although the mechanism by which folic acid exerts its protective effect is unclear, the teratogenic process resulting from folate insufficiency may be related to hyperhomocysteinemia (Nelen, 2001; Vollset et al., 2000). Methylenetetrahydrofolate reductase (MTHFR) gene polymorphism is an important genetic factor for hyperhomocysteinemia (Sibani et al.,2000).

MTHFR is a critical enzyme in folate and methionine metabolism. It irreversibly catalyzes the reduction of 5,10methylene-tetrahydrofolate to 5-methyltetrahydrofolate, which one is the methyl donor for the conversion of homocysteine to methionine (Goyette et al., 1994). Several folate pathway genes showed single nucleotide polymorphism (SNPs) and frequency of these polymorphisms varies greatly word wide (Rai et al.,2010,2012a,b,2013; Yadav et al., 2017). The MTHFR gene is located on chromosome 1p36.3. Among all the identified polymorphisms, C677T and A1298C polymorphisms are clinically important and variant MTHFR enzymes (Ala222Val and Glu429ALa) are associated with reduced enzyme activity and hyperhomocysteinemia (Frosst et al.,1995; Weisberg et al.,1998; Rozen,1997).

A1298C polymorphism involves A to C nucleotide substitution at 1298th position (Weisberg et al. 1998), leading to a glutamate to alanine substitution (Glu429Ala) in the MTHFR protein. Glutamate to alanine amino acid substitution at 429th position in MTHFR enzyme, reduces $40 \%$ enzyme activity. A1298C allele frequency differs greatly in various ethnic groups of the world. The prevalence of the A1298C homozygote variant genotype ranges from 7 to $12 \%$ in White populations from North America and Europe and lower frequencies have been reported in Hispanics (4 to $5 \%$ ) and Asian populations (1 to 4\%) (Botto and Young, 2000). MTHFR A1298C gene polymorphism is associated with a number of diseases like- Down syndrome (Rai et al., 2006), neural tube defects (van der Put et al., 1997), cleft lip and palate (Chorna et al.,20011) and psychiatric disorders (Sazci et al., 2005) etc. Numerous case control studies were investigated the association between maternal MTHFR A1298C polymorphism and CHD but the results were contradictory. Hence, we performed meta-analysis of case control studies to conclude the role of maternal MTHFR A1298C polymorphism in fetal CHD risk.

\section{Methods:}

Article search was carried out in four electronic databases (Pubmed, Google scholar, Elsevier and Springer Link) up to June, 2018 using key terms - 'methylenetetrahydrofolate reductase or MTHFR', 'A1298C' , 'polymorphism' and 'congenital heart disease or CHD'. Reference list of eligible articles were also searched for relevant studies.

\section{Data selection:}


Following data from each included article were extracted: author name; ethnicity; country of origin; journal name; year of publication; number of cases and controls; and number of MTHFR A1298C genotypes in mothers of CHD cases and mothers of healthy children as controls. Inclusion and exclusion criteria:

A strict inclusion and exclusion criteria was followed to select the studies for meta-analysis. Criteria for inclusion were as follows; (i) article should evaluated the association of maternal MTHFR A1298C gene polymorphism with CHD; (ii) article should be case-control association study; and (iii) the articles must report the sample size, distribution of alleles or genotypes for estimating the odds ratio (ORs) with 95\% confidence interval (CIs). Studies were excluded if one of the following existed: (i) case-only studies, (ii) studies that contained duplicate data, and (iii) editorial, case reports or reviews.

\section{Statistical analysis:}

The present meta-analysis examined the overall association of maternal mutant $\mathrm{C}$ allele with the risk of CHD. The associations were indicated as odds ratios (ORs) with the corresponding $95 \% \mathrm{CI}$. The OR was estimated either by using fixed effects (Mantel and Haenszel, 1959) or random effects (DerSimonian and Laird, 1986) model depending upon heterogeneity. The heterogeneity between studies was tested using the Q-statistic and quantified by $\mathrm{I}^{2}$ statistic (Higgins et al., 2002).

\section{Sensitivity analysis:}

The distribution of the genotypes in the control group was tested for Hardy Weinberg equilibrium (HWE) and sensitivity analysis performed by exclusion of the studies in which control population was not in HWE.

\section{Publication bias:}

Publication bias was investigated by using funnel plots of standard error and precision. Egger's regression intercept (Egger et al.,1997) was used to assess the publication bias. All $\mathrm{p}$ value were two sided, and $\mathrm{p}$ values $<0.05$ were considered statistically significant. All statistical analyses were performed using the computer program MIX version 1.7 (Bax et al., 2006) and MetaAnalyst (Wallace et al.,2013).

\section{Results:}

\section{Characteristics of included studies:}

Total seventeen studies (Storti et al.,2003; Nurk et al.,2004; Galdieri et al., 2007; Van Driel et al.,2008; Xu et al., 2010; Bozovic et al.,2011; Obermann-Borst et al.,2011; Weiner et al., 2012; Christense et al., 2013; Wang et al.,2013; Zidan et al.,2013; Huang et al.,2014; Sahiner et al.,2014; Li et al.,2015; Sayin et al.2015; Shi et al.,2015; Feng et al.,2016) were found suitable for the inclusion in present meta-analysis. The studies were published between 2003 and 2015. All these nine studies were performed in different countries- Brazil (Galdieri et al., 2007), China (Xu et al., 2010; Wang et al.,2013; Huang et al.,2014; Li et al.,2015; Sayin et al.2015; Shi et al.,2015; Feng et al.,2016), Croatia (Bozovic et al.,2011), Egypt (Zidan et al.,2013), Italy (Storti et al.,2003), Netherland (ObermannBorst et al.,2011), Norway (Nurk et al.,2004; Van Driel et al.,2008), Russia (Weiner et al., 2011), Turkey (Sahiner et al.,2014), and USA (Christense et al., 2013). The lowest sample size was 25 (Nurk et al., 2004) and highest sample size was 502 (Xu et al., 20101) in included studies. Total number of cases were 2514 with genotype percentage of $\mathrm{AA}, \mathrm{AC}$ and $\mathrm{CC}$ was $56.96 \%, 34.88 \%$ and $8.15 \%$ respectively. Total number of controls were 17,226 with genotypes percentage of AA, AC and CC were $47.53 \%, 42.51 \%$ and $9.95 \%$ respectively.

\section{Meta-analysis:}

In allele contrast meta-analysis, maternal mutant $\mathrm{C}$ allele showed significant association with $\mathrm{CHD}$ in fixed effect $(\mathrm{OR}=1.14,95 \% \mathrm{CI}=1.03-1.24, \mathrm{p}=0.007)$ and random effect $(\mathrm{OR}=1.19,95 \% \mathrm{CI}=0.95-1.36, \mathrm{p}=0.04)$ models (Table 2, Figure 1). Similar to allele contrast meta-analysis, pooled odds ratio for maternal mutant homozygote genotype (CC vs. AA) also showed significant association with $\mathrm{CHD}$ adopting both fixed $(\mathrm{OR}=1.40,95 \% \mathrm{CI}=1.11-1.46, \mathrm{p}=$ $0.004)$ and random $(\mathrm{OR}=1.46,95 \% \mathrm{CI}=1.00-2.13, \mathrm{p}=0.04)$ effect models (Figure 2). Association of mutant heterozygous genotype (AC vs. AA; co-dominant model) did not show any association with CHD using fixed and random effect models. Dominant maternal mutant genotypes (CC+AC vs. AA; dominant model) showed significant association with $\mathrm{CHD}$ using both fixed $(\mathrm{OR}=1.13$; $95 \% \mathrm{CI}=1.0-1.26 ; \mathrm{p}=0.04)$ and random $(\mathrm{OR}=1.19 ; 95 \% \mathrm{CI}=$ 0.97-1.4; $\mathrm{p}=0.04$ ) effect models (Figure 3; Table 2). Meta-analysis using recessive genetic model (CC vs. AC+AA; recessive model) showed significant association with $\mathrm{CHD}$ with fixed $(\mathrm{OR}=1.34 ; 95 \% \mathrm{CI}=1.1-1.6 ; \mathrm{p}=0.01)$ and random $(\mathrm{OR}=1.34 ; 95 \% \mathrm{CI}=0.99-1.81 ; \mathrm{p}=0.28)$ effect models (Figure 4; Table 2).

A insignificant low heterogeneity existed in between studies for recessive model $\left(\mathrm{P}_{\text {heterogeneity }}=0.06, \mathrm{I}^{2}=37.8 \%\right)$, significant heterogeneity existed between studies for allele contrast $\left(\mathrm{P}_{\text {heterogeneity }}=0.0001, \mathrm{I}^{2}=65.04 \%\right)$, dominant model $\left(\mathrm{P}_{\text {heterogeneity }}=0.0005, \mathrm{I}^{2}=61.34 \%\right)$, high heterogeneity existed between studies for homozygote $\left(\mathrm{P}_{\text {heterogeneity }}\right.$ $=0.005, \mathrm{I}^{2}=53.68 \%$, ) and co-dominant $\left(\mathrm{P}_{\text {heterogeneity }}=0.006, \mathrm{I}^{2}=52.23 \%,\right)$ comparisons.

\section{Publication bias:}

Funnel plots using standard error and precision values for allele and genotypes using random effect model were generated (Table 2; Figure 5,6). Symmetrical distribution of studies in the funnel plots suggests absence of 
publication bias except co-dominant model. This is also supported by Eggers test ( $p=0.29$ for $\mathrm{C}$ vs. $\mathrm{A} ; \mathrm{p}=0.21$ for $\mathrm{CC}$ vs $\mathrm{AA} ; \mathrm{p}=0.21$ for $\mathrm{CC}+\mathrm{AC}$ vs. $\mathrm{AA} ; \mathrm{p}=0.57$ for $\mathrm{CC}$ vs. $\mathrm{AC}+\mathrm{AA}$ and $\mathrm{p}=0.04$ for $\mathrm{AC}$ vs. $\mathrm{AA}$ ) (Table 2).

\section{Discussion:}

Normal MTHFR activity is crucial to maintain the pool of circulating folate and methionine and to prevent the accumulation of homocysteine (Frosst et al., 1995). Numerous case control studies have indicated an effect of the maternal MTHFR genotype rather than that of the affected child (Martinelli et al, 2001; Prescott et al, 2002) on fetal development. The association of MTHFR polymorphisms with the increased risk of CHD supports the protective effect of maternal use of folic acid with respect to the occurrence of CHD.

Folate deficiency and hypofunction of MTHFR enzyme activity were affected cell proliferation and apoptosis in developing fetus. Embryonic heart development is a complex process and proliferation and apoptosis play important roles (Fisher et al., 2000; Gittenberger-de Groot et al.,2005; Li et al., 2005). Inadequate proliferation or excess apoptosis can directly or indirectly result in CHD( Kruman et al.,2005). However, it is not clear whether folate deficiency alters proliferation/ apoptosis in the heart or not (Li et al.,2005). MTHFR gene knock out mice have reduced concentration of S-adenosylmethionine and increased concentration of S-adenosylhomocysteine, showed hyperhomocysteinemia and global DNA hypomethylation (Chen et al., 2001)

Meta-analysis is a statistical tool which is successfully used for combining results of several small, low powered case control studies to conclude the results with less statistical error and high statistical power. Numerous metaanalyses were published to confirm the small effect of gene polymorphism as risk factor for several disease likecleft lip and palate (Rai,2014a,2018b); NTD (Yadav et al., 2015); male infertility (Rai and Kumar,2017d), Down syndrome (Rai,2011a; Rai et al.,2017c; Rai and Kumar,2018a); recurrent pregnancy loss (Rai,2016a), glucose 6phosphate dehydrogenase deficiency (Kumar et al.,2016), bipolar disorder (Rai,2011b), Schizophrenia( Yadav et al.2016a, Rai et al.,2017e), autism (Rai,2016c; Rai and Kumar,2018c), Depression (Rai,2014c); Alzheimers disease (Rai,2016b,2017a); epilepsy (Rai and Kumar, 2018d), Uterine Leiomyoma (Kumar and Rai, 2018a), hyperurecemia (Rai,2016d), breast cancer (Rai,2014b; Rai et al.,2017b), esophageal cancer (Kumar and Rai, 2018b), lung cancer (Rai,2014d), prostate cancer (Yadav et al.,2016b),colorectal cancer (Rai,2015), digestive tract cancer (Yadav et al.,2018), endometrial cancer (Kumar and Rai, 2018c) and ovary cancer (Rai,2016e).

There are several limitations in current meta-analysis, which should be acknowledged- (i) unadjusted OR was used as association measure, (ii) only one gene polymorphism (MTHFR A1298C) was considered in present metaanalysis, (iii) only four databases were searched for studies, and (iv) gene- gene and gene -environmental interactions were not considered.

In conclusion, results of meta-analysis showed that maternal MTHFR A1298C polymorphism is a risk factor for congenital heart defects in fetus. Periconceptional intake of folate reduces the risk of congenital defects, because it donates methyl group for conversion of homocysteine to methionine and protect fetus from the teratogenic effect of higher concentration of homocysteine. Simultaneously methionine donates methyl group to S-adenosylmethionine for cellular methylation reactions in fetus and due to reduced MTHFR enzyme activity genomic hypomethylation occurs which affects gene expression in developing fetus. In future, larger studies from different regional as well as different ethnic population are required to find out the exact effect of maternal MTHFR A1298C polymorphism on fetal heart.

\section{Conflict of interest: None References:}

Bax L, Yu LM, Ikeda N, Tsuruta H, Moons KG (2006) Development and validation of MIX: comprehensive free software for meta-analysis of causal research data. BMC Med Res Methodol 6: 50-52.

Botto LD, Young Q (2000) 5,10-Methylenetetrahydrofolate reductase gene variants and congenital anomalies: a HuGE review. Am J Epidemiol 151(9):862-77.

Bozovic IB, Vranekovic J, Cizmarevic NS, Mahulja-Stamenkovic V, Prpic I, Brajenovic-Milic B (2011) MTHFR C677T and A1298C polymorphisms as a risk factor for congenital heart defects in Down syndrome. Pediatr Int 53: 546-550.

Chen Z, Karaplis AC, Ackerman SL, Pogribny IP, Melnyk S, et al. (2001) Mice deficient in methylenetetrahydrofolate reductase exhibit hyperhomocysteinemia and decreased methylation capacity, with neuropathology and aortic lipid deposition. Hum Mol Genet 10: 433-443.

Chorna LB, Akopyan HR, Makukh HV, Fedoryk IM (2011) Allelic Polymorphisms in the MTHFR, MTR and MTRR genes in patients with cleft lip and/or palate and their mothers. Cytology and Genetics 45: 177-181.

Christensen KE, Deng L, Leung KY, Arning E, Bottiglieri T, Malysheva OV, Caudill MA, Krupenko NI, Greene ND, JeromeMajewska L, MacKenzie RE, Rozen R (2013) A novel mouse model for genetic variation in 10-formyltetrahydrofolate 
medRxiv preprint doi: https://doi.org/10.1101/19010298; this version posted November 2, 2019. The copyright holder for this preprint (which was not certified by peer review) is the author/funder, who has granted medRxiv a license to display the preprint in perpetuity. It is made available under a CC-BY-ND 4.0 International license .

synthetase exhibits disturbed purine synthesis with impacts on pregnancy and embryonic development. Hum Mol Genet 22(18):3705-19.

Christensen KE, Zada YF, Rohlicek CV, Andelfinger GU, Michaud JL, Bigras JL, Richter A, Dube MP, Rozen R (2013) Risk of congenital heart defects is influenced by genetic variation in folate metabolism. Cardiol Young 223:89-98.

Czeizel AE, Dudas I (1992) Prevention of the first occurrence of neural-tube defects by periconceptional vitamin supplementation. N Engl J Med 327: 1832-1835.

DerSimonian R, Laird N (1986) Meta-analysis in clinical trials. Control Clin Trials 7: 177-88.

Egger M, Davey Smith G, Schneider M, Minder C (1997) Bias in meta-analysis detected by a simple, graphical test. BMJ 315: 629-634.

Feng ZS, Zhao MC, Wang L, Li GX, Tao SG, Wen LL, Wang K, Ma XJ (2016) The investigation of correlation between MTHFR gene polymorphism and congenital heart disease by means of GeXP multiplex analysis technique. J Hebei Med 38:1143-1146.

Fisher SA, Langille BL, Srivastava D (2000) Apoptosis during cardiovascular development. Circ Res 87:856-64.

Frosst P, Blom H J, Milos R, Goyette P, Sheppard C A, Matthews R G, Boers GJH, Heijer M, Kluijtmans LAJ, Heuve LP, Rozen $\mathrm{R}$ (1995) A candidate genetic risk factor for vascular disease: A common mutation in methylenetetrahydrofolate reductase. Nat Genet 10(1):111-3.

Galdieri LC, Arrieta SR, Silva CM, Pedra CA, D'Almeida V (2007) Homocysteine concentrations and molecular analysis in patients with congenital heart defects. Arch Med Res 38 : 212-218.

Gittenberger-de Groot AC, Bartelings MM, Deruiter MC, Poelmann RE (2005) Basics of cardiac development for the understanding of congenital heart malformations. Pediatr Res 57:169-76.

Goyette P, Sumner JS, Milos R, Duncan AM, Rosenblatt DS, Matthews RG, Rozen R (1994) Human methylenetetrahydrofolate reductase: isolation of cDNA, mapping and mutation identification. Nat Genet 7(2):195-200.

Higgins J, Thompson S, Deeks J, Altman D (2002) Statistical heterogeneity in systematic reviews of clinical trials: A critical appraisal of guidelines and practice. J Health Serv Res Policy 7: 51-61.

Hofmann JIE, Christianson R (1978) Congenital heart disease in a cohort of 19,502 births with long-term follow up. Am J Cardiol 42: 641-647.

Huang J, Mei J, Jiang L, Jiang Z, Liu H, Ding F (2014) MTHFR rs1801133 C>T polymorphism is associated with an increased risk of tetralogy of Fallot. Biomed Rep 2:172-176.

Kruman II, Mouton PR, Emokpae R, Cutler RG, Mattson MP (2005) Folate deficiency inhibits proliferation of adult hippocampal progenitors. Neuroreport16:1055-1059.

Kumar P, Yadav U, Rai V (2015) Methylenetetrahydrofolate reductase gene C677T risk: Evidence for genetic susceptibility. Meta Gene $6: 72-84$.

polymorphism and breast cancer

Kumar P, Yadav U, Rai V (2016) Prevalence of glucose 6-pohsphate dehydrogenase deficiency in India: An updated metaanalysis. Egypt J Med Hum Genet 17:295-302.

Kumar, P., Rai, V.2018. Catechol-O-Methyltransferase Val158Met polymorphism and susceptibility to Uterine Leiomyoma. Jacobs Journal of Gynecology and Obstetrics,2018a; 5(1): 043.

Kumar P, Rai V. Methylenetetrahydrofolate reductase C677T polymorphism and risk of esophageal cancer: An updated metaanalysis. Egypt J Med Hum Genet. 2018b; 19(4): 273-284.

Kumar, P., Singh, G., Rai, V. 2018. Evaluation of COMT gene rs4680 polymorphism as a risk factor for endometrial cancer. IJCB ,2018c; 10.1007/s12291-018-0799-x.

Li D, Pickell L, Liu Y, Wu Q, Cohn JS, Rozen R (2005) Maternal methylenetetrahydrofolate reductase deficiency and low dietary folate lead to adverse reproductive outcomes and congenital heart defects in mice. Am J Clin Nutr 82:188-95. 
medRxiv preprint doi: https://doi.org/10.1101/19010298; this version posted November 2, 2019. The copyright holder for this preprint (which was not certified by peer review) is the author/funder, who has granted medRxiv a license to display the preprint in perpetuity. It is made available under a CC-BY-ND 4.0 International license .

Li Z, Jun Y, Zhong-Bao R, Jie L, Jian-Ming L (2015) Association between MTHFR C677T polymorphism and congenital heart disease. A family-based meta-analysis. Herz 40:S160-167.

Mantel N, Haenszel W (1959) Statistical aspects of the analysis of data from retrospective studies of disease. J Natl Cancer Inst 22(4): 719-48.

Martinelli P, Grandone E, Colaizzo D, Paladini D, Sciannamé N, Margaglione M, Di Minno G (2001) Familial thrombophilia and the occurrence of fetal growth restriction. Haematologica 86(4):428-31.

Mitchell SC, Korones SB, Berendes HW (1971).. Congenital heart disease in 56,109 births. Incidence and natural history. Circulation 43: 323-332.

Nelen WL (2001) Hyperhomcysteinaemia and human reproduction. Clin Chem Lab Med 39(8): 758-763.

Nurk E, Tell GS, Refsum H, Ueland PM, Vollset SE (2004) Associations between maternal methylenetetrahydrofolatereductase polymorphisms and adverse outcomes of pregnancy: The Hordaland Homocysteine Study. Am J Med 117: 26-31.

Obermann-Borst SA, van Driel LM, Helbing WA, de Jonge R, Wildhagen MF, Steegers EA, Steegers- Theunissen RP (2011) Congenital heart defects and biomarkers of methylation in children: a case-control study. Eur J Clin Invest 41:143-150.

Prescott NJ, Winter RM, Malcolm S (2002) Maternal MTHFR genotype contributes to the risk of non-syndromic cleft lip and palate. J Med Genet 39(5):368-9.

Rai V, Yadav U, Kumar P, Yadav SK (2010) Methyleletetrahydrofolate reductase polymorphism (C677T) in Muslim population of Eastern Uttar Pradesh, India. Ind J Med Sci 64(5): 219-223.

Rai V (2011a) Polymorphism in folate metabolic pathway gene as maternal risk factor for Down syndrome. Int J Biol Med Res 2(4): 1055-1060.

Rai V (2011b) Evaluation of methylenetetrahydrofolate reductase gene variant (C677T) as risk factor for bipolar disorder. Cell Mol Biol 57:1558- 1566.

Rai AK, Singh S, Mehta S, Kumar A, Pandey LK, Raman R (2006) MTHFR C677T and A1298C polymorphisms are risk factors for Down's syndrome in Indian mothers. J Hum Genet 51:278-283.

Rai V, Yadav U, Kumar P (2012a) Genotype prevalence and allele frequencies of 5,10-methylenetetrahydrofolate reductase (MTHFR) C677T mutation in two caste groups of India. Cell Mol Biol 58: OL1695- 701.

Rai V, Yadav U and Kumar P (2012b) MTRR A66G polymorphism among two caste groups of Uttar Pradesh (India). Ind J Med Sci 66:136-40.

Rai V, Yadav U, Kumar P, Yadav SK (2013) Analysis of methionine synthase reductase polymorphism (A66G) in Muslim population. Ind J Hum Genet 19:183-187.

Rai V (2014a) Maternal methylenetetrahydrofolate reductase (MTHFR) gene A1298C polymorphism and risk of nonsyndromic Cleft lip and/or Palate (NSCL/P) in offspring: A meta-analysis. Asian J Medical Sciences 6 (1):16- 21.

Rai V (2014b) Methylenetetrahydrofolate reductase A1298C polymorphism and breast cancer risk: a meta-analysis of 33 studies. Annals of Medical and Health Sciences Research 4 (6): 841-851.

Rai V (2014c) Genetic polymorphisms of methylenetetrahydrofolate reductase (MTHFR) gene and susceptibility to depression in Asian population: a systematic meta-analysis. Cell Mol Biol 60 (3): 29-36.

Rai V (2014d) Folate pathway gene MTHFR C677T polymorphism and risk of lung cancer in Asian populations. Asian Pac J Cancer Prev 15: 9259-64.

Rai V (2015) Evaluation of the MTHFR C677T polymorphism as a risk factor for colorectal cancer in Asian populations. Asian Pac J Cancer Prev 16 (18): 8093-8100 .

Rai V (2016a) Methylenetetrahydrofolate reductase C677T polymorphism and recurrent pregnancy loss risk in Asian population: a meta-analysis. Ind J Clin Biochem 31:402-413.

Rai V (2016b) Folate pathway gene methylenetetrahydrofolate reductase C677T polymorphism and Alzheimer disease risk in Asian population. Ind J Clin Biochem 31(3):245-52. 
medRxiv preprint doi: https://doi.org/10.1101/19010298; this version posted November 2, 2019. The copyright holder for this preprint (which was not certified by peer review) is the author/funder, who has granted medRxiv a license to display the preprint in perpetuity. It is made available under a CC-BY-ND 4.0 International license .

Rai V (2016c) Association of methylenetetrahydrofolate reductase (MTHFR) gene C677T polymorphism with autism: evidence of genetic susceptibility. Metab Brain Disease 31: 727-735.

Rai V (2016d) The MTHFR C677T polymorphism and hyperuricemia Risk: a meta-analysis of 558 cases and 912 controls. Metabolomics 6: doi.org/10.4172/2153-0769.1000166.

Rai V (2016e) Methylenetetrahydrofolate reductase gene C677T polymorphism and its association with ovary cancer. J Health Med Informat 7: 3, doi.org/10.4172/2157-7420.1000226.

Rai V (2017a) Methylenetetrahydrofolate reductase (MTHFR) C677T polymorphism and Alzheimer disease risk: a metaanalysis. Mol Neurobio 54:1173-1186.

Rai V, Yadav U, Kumar P (2017b) Impact of catechol-O-Methyltransferase Val 158Met (rs4680) polymorphism on breast cancer susceptibility in Asian population. Asian Pac J Cancer Prev 18 (5): 1243-1250.

Rai V, Yadva U, Kumar P (2017c) Null association of maternal MTHFR A1298C polymorphism with Down syndrome pregnancy: An updated meta-analysis. Egyptian J Med Hum Genet 18(1): 9-18.

Rai V, Kumar P (2017d) Methylenetetrahydrofolate reductase C677T polymorphism and risk of male infertility in Asian population. Ind J Clin Biochem 32(3): 253-260.

Rai V, Yadav U, Kumar P, Yadav SK, Gupta S (2017e) Methylenetetrahydrofolate reductase A1298C genetic variant and risk of schizophrenia: an updated meta-analysis. Indian J Med Res 145(4):437.

Rai V, Kumar P (2018a) Fetal MTHFR C677T polymorphism confers no susceptibility to Down Syndrome: evidence from meta-analysis. Egyptian J Med Hum Genet .19:53-58.

Rai V (2018b) Strong association of C677T polymorphism of methylenetetrahydrofolate reductase gene with nosyndromic cleft lip/palate (nsCL/P). Ind J Clin Biochem 33(1):5-15.

Rai V, Kumar P (2018c) Methylenetetrahydrofolate reductase A1298C polymorphism and autism susceptibility. Austin Journal of Autism \& Related Disabilities 4: 1048-1053.

Rai, V., Kumar, P. 2018. Methylenetetrahydrofolate reductase C677T polymorphism and susceptibility to epilepsy. Neurol Sci. 2018d; 10.1007/s10072-018-3583-z.

Rozen R (1997) Genetic predisposition to hyperhomocysteinemia: deficiency of methylenetetrahydrofolate reductase (MTHFR). Thromb Haemost 78: 523- 526.

Sahiner UM, Alanay Y, Alehan D, Tuncbilek E, Alikasifoglu M (2014) Methylene tetrahydrofolate reductase polymorphisms and homocysteine level in heart defects. Pediatr Int 56:167-172.

Sazci A, Ergul E, Kucukali I, Kara I, Kaya G (2005) Association of the C677T and A1298C polymorphisms of methylenetetrahydrofolate reductase gene with schizophrenia: association is significant in men but not in women. Prog Neuropsychopharmacol Biol Psychiatry 29(7): 1113-1123.

Sayin Kocakap BD, Sanli C, Cabuk F, Koc M, Kutsal A (2015) Association of MTHFR A1298C polymorphism with conotruncal heart disease. Cardiol Young 25:1326-1331.

Shi H, Yang S, Liu Y, Huang P, Lin N, Sun X, Yu R, Zhang Y, Qin Y, Wang L (2015) Study on Environmental Causes and SNPs of MTHFR, MS and CBS Genes Related to Congenital Heart Disease. PloS One 10:e0128646.

Sibani S, Christensen B, O'Ferrall E, Saadi I, Hiou-Tim F, Rosenblatt DS, Rozen R (2000) Characterization of six novel mutations in the methylenetetrahydrofolate reductase (MTHFR) gene in patients with homocystinuria. Hum Mutat 15: $280-287$.

Storti S, Vittorini S, Lascone M R, Sacchelli M, Collavoli A, Ripoli A, Cocchi G, Biagini A, Clerico A (2003) Association between 5,10-methylenetetrahydrofolate reductase C677T and A1298C polymorphisms and conotruncal heart defects. Clin Chem Lab Med 41: 276-280.

van der Put NM, Eskes TK, Blom HJ (1997) Is the common 677CT mutation in the methylenetetrahydrofolate reductase gene a risk factor for neural tube defects? A meta-analysis. Q J Med 90:111-115. 
medRxiv preprint doi: https://doi.org/10.1101/19010298; this version posted November 2, 2019. The copyright holder for this preprint (which was not certified by peer review) is the author/funder, who has granted medRxiv a license to display the preprint in perpetuity. It is made available under a CC-BY-ND 4.0 International license .

van Driel LM, Verkleij-Hagoort AC, de Jonge R, Uitterlinden AG, Steegers EA, van Duijn CM, Steegers- Theunissen RP (2008) Two MTHFR polymorphisms, maternal B-vitamin intake, and CHDs. Birth Defects Res A Clin Mol Teratol 2008;82:474-481.

Vollset SE, Refsum H, Irgens LM, Emblem BM, Tverdal A, Gjessing HK, Monsen AL, Ueland PM (2000) Plasma total homocystein, pregnancy complications, and adverse pregnancy outcomes: the hordaland homocysteine study. Am J Clin Nutr 71: 962-968.

Wallace BC, Dahabreh IJ, Trikalinos TA, Lau J, Trow P, Schmid CH (2013) Closing the Gap Between Methodologists and EndUsers: R as a Computational Back-end. J Stat Software 49:1-15.

Wang B, Liu M, Yan W, Mao J, Jiang D, Li H, Chen Y (2013) Association of SNPs in genes involved infolate metabolism with the risk of congenital heart disease. J Matern Fetal Neonatal Med 26:1768-1777.

Weiner AS, Gordeeva LA, Voronina EN, Boyarskikh UA, Shabaldin AV, Filipenko ML (2012) Polymorphisms in folatemetabolizing genes and risk of having an offspring with congenital anomalies in the West Siberian region of Russia: a casecontrol study. Prenat Diagn 32(11):1041-8.

Weisberg I, Tran P, Christensen B, Sibani S, Rozen R (1998) A second genetic polymorphism in methylenetetrahydrofolate reductase (MTHFR) associated with decreased enzyme activity. Mol Genet Metab 64: 169-172.

Winter S, Hafner E, Stonek F, Stuempflen I, Metzenbauer M, Philipp K (2007) Association of congenital cardiac defects and the C677T methylenetetrahydrofolate reductase polymorphism. Prenat Diagn 27: 704-708.

Xu J, Xu X, Xue L, Liu X, Gu H, Cao H, Qiu W, Hu Z, Shen H, Chen Y (2010) MTHFR c.1793G>A polymorphism is associated with congenital cardiac disease in a Chinese population. Cardiol Young 20: 318-326.

Yadav U, Kumar P, Yadav SK, Mishra OP, Rai V (2015) Polymorphisms in folate metabolism genes as maternal risk factor for Neural Tube Defects: an updated meta-analysis. Metabolic Brain Disease 30:7-24.

Yadav U, Kumar P, Gupta S, Rai V (2016a) Role of MTHFR C677T gene polymorphism in the susceptibility of schizophrenia: An updated meta-analysis. Asian J Psychiatry 20: 41-51.

Yadav U, Kumar P, Rai V (2016b) Role of MTHFR A1298C gene polymorphism in the etiology of prostate cancer: a systematic review and updated meta-analysis. Egyp J Med Hum Genet 17(2): 141-148.

Yadav U, Kumar P, Gupta S, Rai V (2017) Distribution of MTHFR C677T gene polymorphism in healthy North Indian population and an updated meta-analysis. Ind J Clinical Biochem 32(4):399-410.

Yadav U, Kumar P, Rai V (2018) NQO1 gene C609T polymorphism (dbSNP: rs1800566) and digestive tract cancer risk: A Meta analysis. Nutrition and Cancer 10.1080/01635581.2018.1460674.

Zidan HE, Rezk NA, Mohammed D (2013) MTHFR C677T and A1298C gene polymorphisms and their relation to homocysteine level in Egyptian children with congenital heart diseases. Gene 529(1):119-24.

Table 1. Distribution of different MTHFR A1298C genotypes in seventeen included meta-analysis

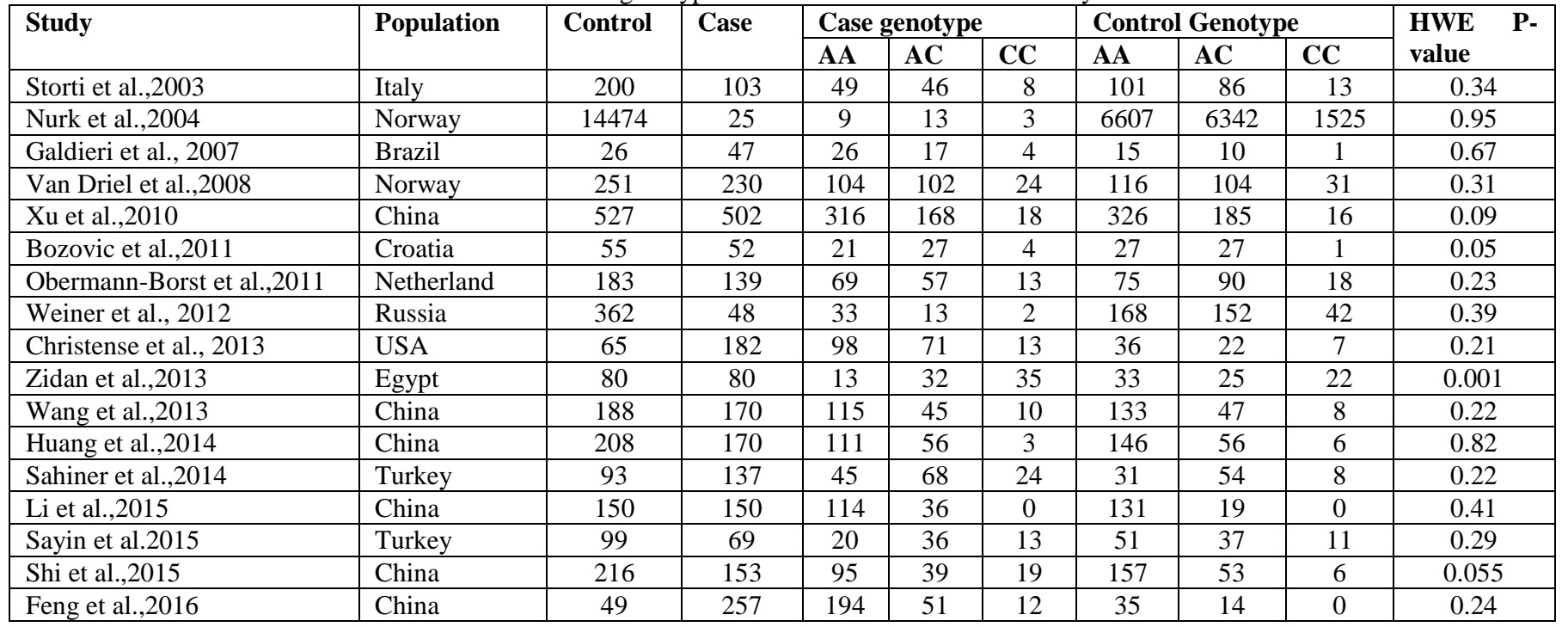


medRxiv preprint doi: https://doi.org/10.1101/19010298; this version posted November 2, 2019. The copyright holder for this preprint (which was not certified by peer review) is the author/funder, who has granted medRxiv a license to display the preprint in perpetuity.

It is made available under a CC-BY-ND 4.0 International license .

Table 2: Summary estimates for the odds ratio (OR) of MTHFR A1298C in various allele/genotype contrasts, the significance level ( $p$ value) of heterogeneity test $\left(Q\right.$ test), and the $I^{2}$ metric and publication bias p-value (Egger Test).

\begin{tabular}{|c|c|c|c|c|c|}
\hline Genetic Models & $\begin{array}{l}\text { Fixed effect } \\
\text { OR }(95 \% \text { CI }), p\end{array}$ & $\begin{array}{l}\text { Random effect } \\
\text { OR }(95 \% \mathrm{CI}), \mathrm{p}\end{array}$ & $\begin{array}{l}\text { Heterogen } \\
\text { eity p- } \\
\text { value (Q } \\
\text { test) }\end{array}$ & $\begin{array}{l}\mathbf{I}^{2} \\
(\%)\end{array}$ & $\begin{array}{l}\text { pvalue } \\
\text { of } \\
\text { Egger's } \\
\text { test }\end{array}$ \\
\hline Allele Contrast (C vs A) & $1.14(1.03-1.24), 0.007$ & $1.19(1.00-1.41), 0.04$ & 0.0001 & 65.04 & 0.29 \\
\hline Co-dominant ( $\mathrm{AC}$ vs AA) & $1.1(0.96-1.22), 0.20$ & $1.13(0.93-1.36), 0.23$ & 0.006 & 52.23 & 0.04 \\
\hline Homozygote (CC vs AA) & $1.40(1.11-1.46), 0.004$ & $1.46(1.00-2.13), 0.04$ & 0.005 & 53.68 & 0.21 \\
\hline Dominant $(\mathrm{CC}+\mathrm{AC}$ vs AA) & $1.13(1.0-1.26), 0.04$ & $1.19(0.97-1.4), 0.04$ & 0.0005 & 61.34 & 0.22 \\
\hline Recessive (CC vs AC+AA) & $1.34(1.1-1.6), 0.01$ & $1.34(0.99-1.81), 0.02$ & 0.06 & 37.8 & 0.57 \\
\hline
\end{tabular}

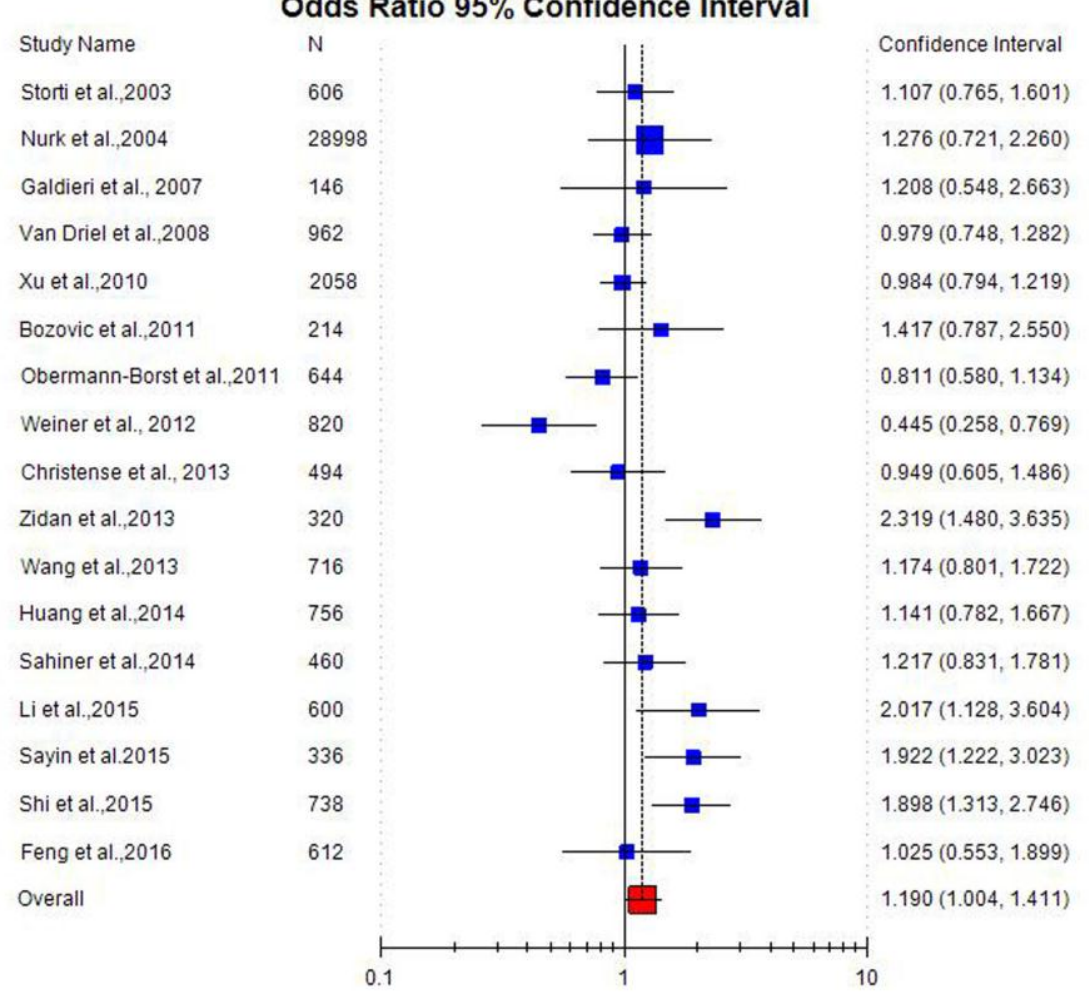

Figure 1: Forest plots (random effect) of allele contrast model (C versus A) showed significant association between maternal MTHFR A1298C polymorphism and CHD risk. 
medRxiv preprint doi: https://doi.org/10.1101/19010298; this version posted November 2, 2019. The copyright holder for this preprint (which was not certified by peer review) is the author/funder, who has granted medRxiv a license to display the preprint in perpetuity.

It is made available under a CC-BY-ND 4.0 International license .

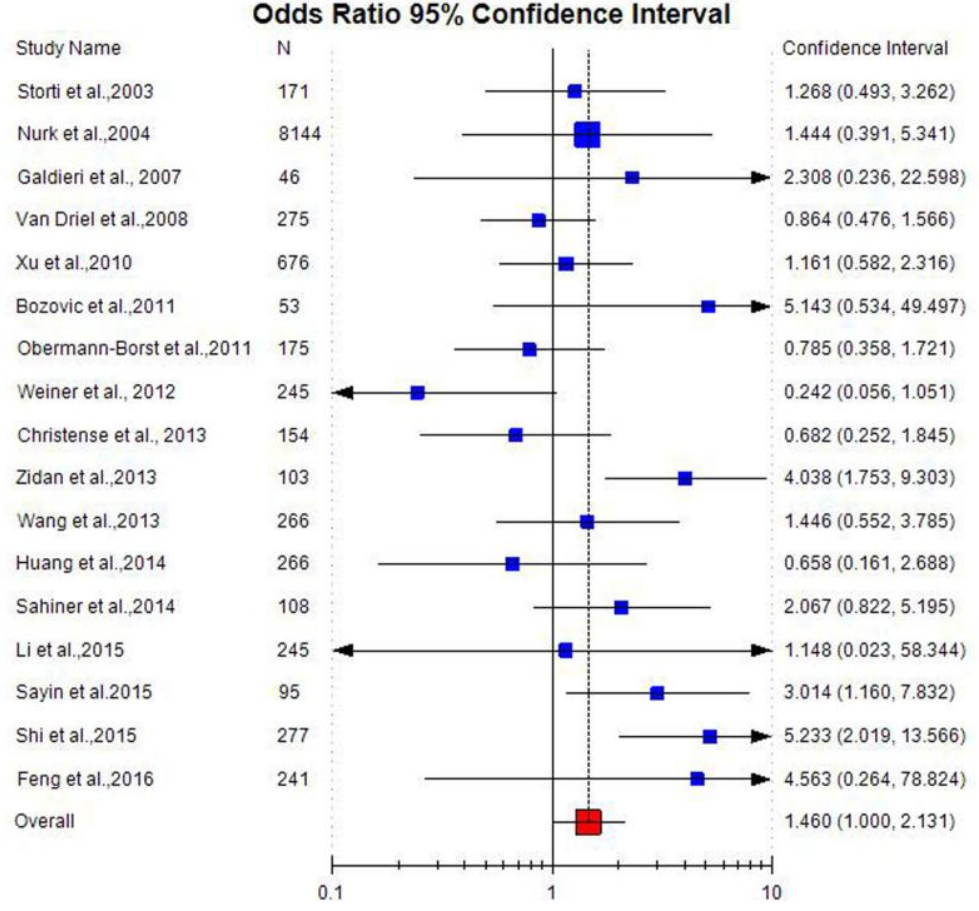

Figure 2: : Forest plots (random effect) of homozygote model (CC versus AA) showed significant association between maternal MTHFR A1298C polymorphism and CHD risk.

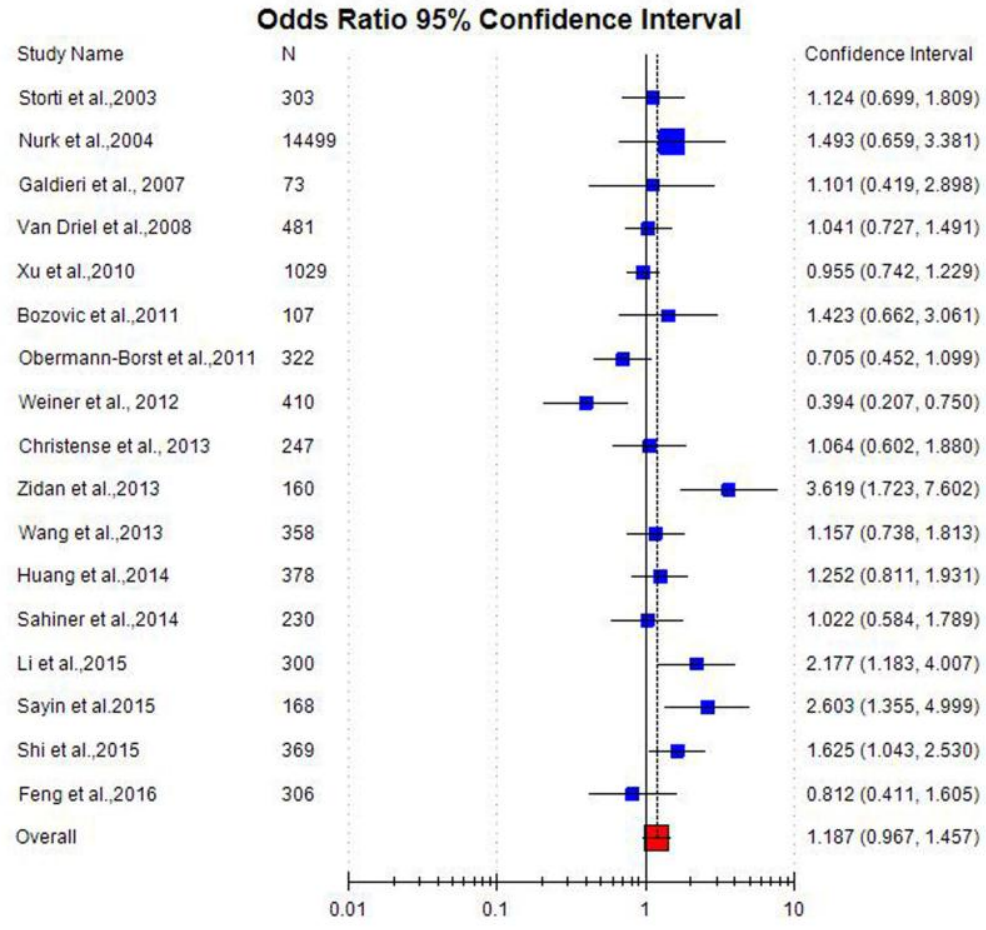

Figure 3: : Forest plots (random effect) of dominant model (CC + AC versus AA) showed significant association between maternal MTHFR A1298C polymorphism and CHD risk. 
medRxiv preprint doi: https://doi.org/10.1101/19010298; this version posted November 2, 2019. The copyright holder for this preprint (which was not certified by peer review) is the author/funder, who has granted medRxiv a license to display the preprint in perpetuity.

It is made available under a CC-BY-ND 4.0 International license .

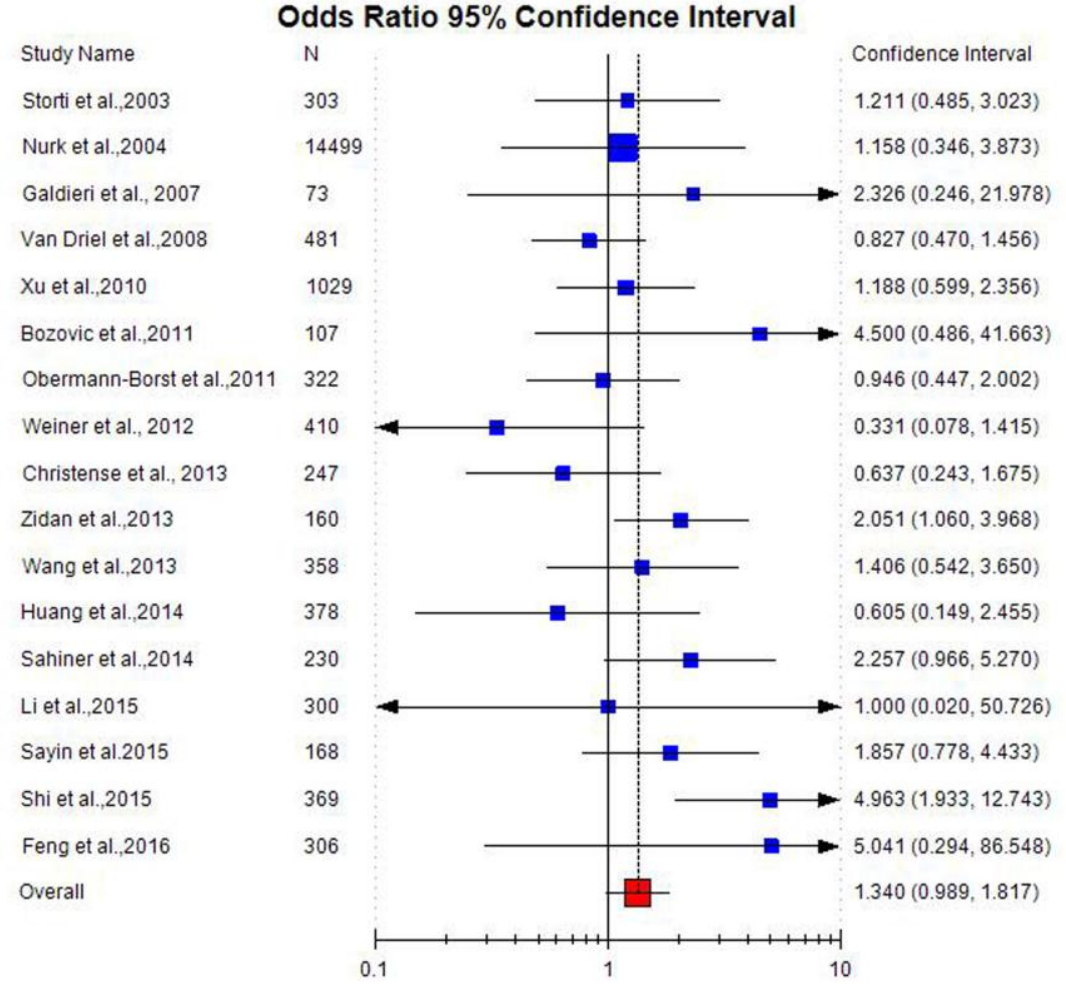

Figure 4: : Forest plots (random effect) of recessive model (CC versus AC+AA) showed significant association between maternal MTHFR A1298C polymorphism and CHD risk.

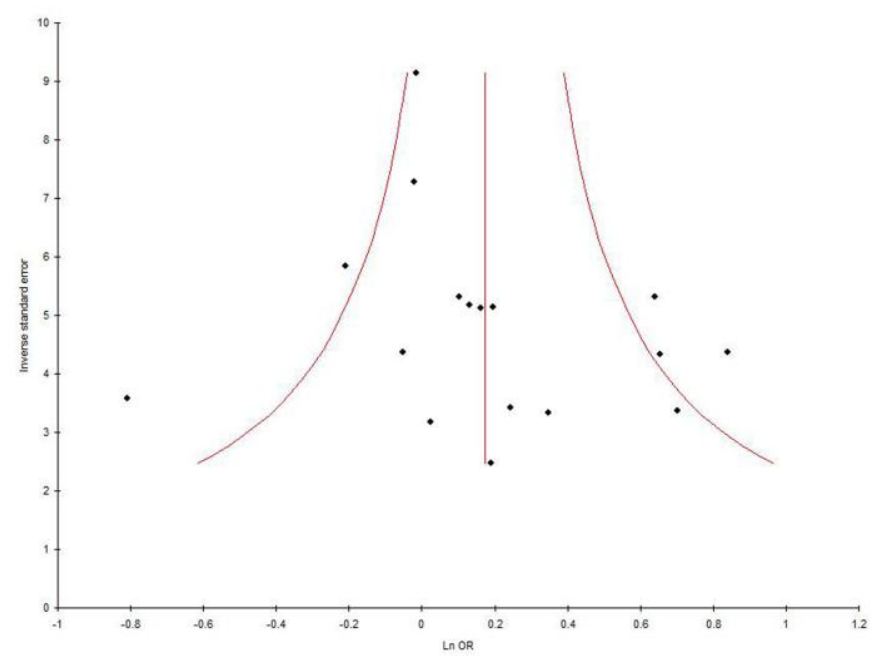

Figure 5: Funnel plots of precision by OR of MTHFR A1298C allele contrast 
medRxiv preprint doi: https://doi.org/10.1101/19010298; this version posted November 2, 2019. The copyright holder for this preprint (which was not certified by peer review) is the author/funder, who has granted medRxiv a license to display the preprint in perpetuity.

It is made available under a CC-BY-ND 4.0 International license.

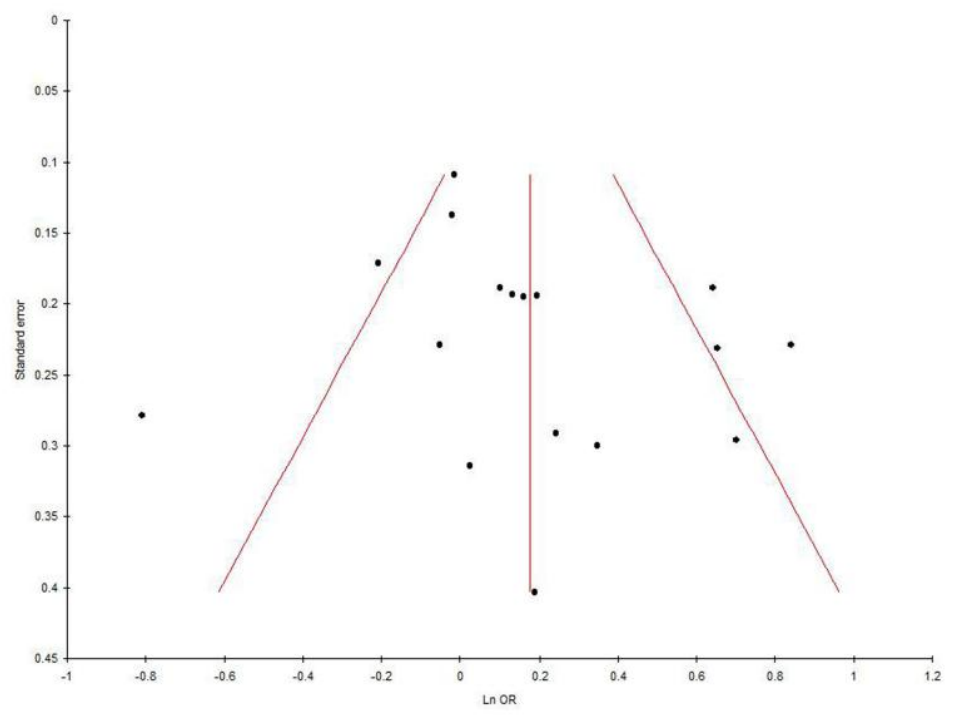

Figure 6. Funnel plots of standard error by OR of MTHFR A1298C allele contrast 